\title{
Use of Phosphorus for Maximization of Mungbean (Vigna radiata L.) (wilszeck) Productivity under Semi-arid Condition of Rajasthan, India
}

\author{
Sunil Kumar ${ }^{1}$, S.S. Yadav ${ }^{2}$, Pradip Tripura ${ }^{3}$ and H.S. Jatav ${ }^{4}$ \\ ${ }^{1}$ Department of Agronomy, IAS, BHU, Varanasi-221 005, India \\ ${ }^{2}$ Department of Agronomy, SKNAU, Jobner-303 329, India \\ ${ }^{3}$ Department of Soil Science and Agricultural Chemistry JAU, Junagharh, India \\ ${ }^{4}$ Department of Soil Science and Agricultural Chemistry, IAS, BHU, Varanasi-221 005, India \\ *Corresponding author
}

\begin{tabular}{|c|c|}
\hline & A B S T R A C T \\
\hline & Pulses occupy unique place in Indian diet with supplying of vegetable protein to primarily \\
\hline Keywords & $\begin{array}{l}\text { starchy diet and provide an essential supplement for balance diet. Therefore, it is essential } \\
\text { to increase the sustainable productivity with more appropriate management of nutrient }\end{array}$ \\
\hline Phosphorus, & utilization of plants so that with same area, we can increase pulses sustainable production. \\
\hline $\begin{array}{l}\text { Optimum dose, } \\
\text { greengram, } \\
\text { Grain yield. }\end{array}$ & $\begin{array}{l}\text { In future sustainable pulse production will greatly depend on soil health because of heavy } \\
\text { doses of chemical fertilizers, extensive removal of phosphorus by the crops under intensive }\end{array}$ \\
\hline Article Info & sustainability in production and environment. In this regard, a field experiment was \\
\hline $\begin{array}{l}\text { Accepted: } \\
\text { 15 January } 2017 \\
\text { Available Online: } \\
12 \text { February } 2017\end{array}$ & $\begin{array}{l}(0,20,40 \text { and } 60 \mathrm{~kg} / \mathrm{ha}) \text { in greengram. Results workout in quadratic equation with four } \\
\text { levels of phosphorus found that } 49.7 \mathrm{~kg} / \mathrm{ha} \text { is proved to be the best dose for optimum input } \\
\text { responsive yield }(1216.6 \mathrm{~kg} / \mathrm{ha} \text {. }) \text {. With this in the experiment we also find out the } \\
\text { correlation and regression between grain yield }(\mathrm{kg} / \mathrm{ha}) \text { and independent variables }(\mathrm{X}) \text {, and } \\
\text { found positive values of all calculated variables. }\end{array}$ \\
\hline
\end{tabular}

\section{Introduction}

Pulses have an important place in order to mitigate the protein requirement of increasing population of country. Greengram as 'Moongbean' or 'moong' contains 24.5 per cent protein, rich in carbohydrates and also contains small quantities of riboflavin and thiamine and fairly rich in phosphorus and iron. It mainly grown as sole crop, mixed crop and intercrop in kharif and in summer season where adequate water availability are available (Bhatt et al., 2013). In India production of pulses accounts 19.77 million tons with an area of $24.79 \mathrm{~m}$ ha. Mungbean
Ranks third after chickpea and pigeanpea among pulses. It covers 29.36 lakh hectare areas with 13.90 lakh tones production in the country (Anonymous, 2014-15a). The important states which lead in mungbean acreage are Rajasthan, Madhya Pradesh, Uttar Pradesh, Orissa, Maharashtra, Karnataka and Bihar. In Rajasthan, total area under mungbean was 8.93 lakh hectare with the production of 4.23 lakh tones and average productivity of $473 \mathrm{~kg} / \mathrm{ha}$ (Anonymous, 2014$15 \mathrm{~b}$ ). Declining productivity of mungbean is mainly due to the cultivation in degraded or 
less fertile soil with less adoption of suitable management technology while, with availability of high yielding short duration cultivars and the suitability of growing them round the year, give a vast opportunity to fulfill the protein requirement by increasing productivity (Singh et al., 1994). To exploit the full genetic potential of improved mungbean variety is may be possible through development of best management practices and improved crop management techniques. In addition to all appropriate cultivation practices application of balanced amount or optimum dose of nutrients, particularly phosphorus can become important element apart from NPK in all the greengram cultivation The incorporation of vermicompost in the soil and the addition of arbuscular mycorrhizal fungi, PSB are promotes soil fertility and plant growth by increasing the nutrient availability and nutrient absorption, especially in reference to $\mathrm{P}$ a nutrient that is found in low levels in tropical soils (Tripura, et al., 2016). Increasing the number of such microorganisms and accelerate microbial process to augment to extent of the availability of the nutrient in a form, which can easily assimilated by plant. Pulses have relatively more requirement of $\mathrm{P}$ among the field crops (Tandon, 1995). However, techniques involving optimization of fertilizer inputs (Phosphorus dose) with aim to enhance the productivity and economics of cultivating mungbean (Sathyamoorthi et al., 2008). Hence the present study was carried out in greengram to found the effect of optimum fertilization through soil on the yield of greengram.

\section{Materials and Methods}

The experiment was carried out at Agriculture Research Farm, SKNAU, Jobner is located at 75028' E-longitude and 26005' N-latitude and at an altitude of 427 meters above mean sea level. In Rajasthan, this region falls under Agro climatic zone IIIa (Semi-Arid Eastern Plains Zone) during kharif season of 2014. The climatic conditions of location are typically semi-arid, characterized by extremes of temperature during both summers and winters. The average annual rainfall of place between $400-500 \mathrm{~mm}$, which is mostly occurred by the S-W monsoon during the months of July and August. A total of rainfall was recorded during cropping season. During the experiment season; the total rainfall was recorded $265 \mathrm{~mm}$ major part of which was received in the month August. The soil of experimental field was loamy sand in texture, alkaline in reaction, poor in organic carbon, low in available nitrogen and phosphorus and medium in available potassium content. The experiment was laid out in randomized block design with three replications, having four levels of phosphorus $\left(\mathrm{P}_{0}, \mathrm{P}_{20}, \mathrm{P}_{40}\right.$ and $\mathrm{P}_{60} \mathrm{~kg}$ $\mathrm{ha}^{-1}$ ). Full quantity of phosphorus (DAP) was applied at the time of sowing as per $\mathrm{P}_{2} \mathrm{O}_{5}$ receiving treatments. The crop was equally fertilized with $25 \mathrm{~kg} \mathrm{~N}^{-1}{ }^{-1}$ with urea as basal dose to each treatment. Seed of cv. RMG-268 (suitable for both, Kharif and Zaid seasons which matures uniformly within 65-70 days) were sown at 3 to $4 \mathrm{~cm}$ depth with $30 \mathrm{~cm}$ spacing at $3^{\text {rd }}$ week of July, 2014. All the recommended cultural and plant protection measures were followed throughout the experimentation.

\section{Results and Discussion}

The data presented in table 1 and fig 1 a critical examination of the data revealed that grain yield of mungbean was significantly improved due to successive increase in level of phosphorus up to $40 \mathrm{~kg} / \mathrm{ha}$. It provide the grain yield of $1190 \mathrm{~kg} / \mathrm{ha}$ and further application of phosphorus up to $60 \mathrm{~kg} / \mathrm{ha}$ produced the highest grain yield of 1214 $\mathrm{kg} / \mathrm{ha}$. However, response of grain yield to varying levels of phosphorus was worked out 
and found to be the quadratic (Table 1 and Fig. 1). The functional form of yield response to phosphorus showed that the economic optimum dose of phosphorus worked out through production function came out 49.7 $\mathrm{kg} / \mathrm{ha}$ corresponding with grain yield response of $1216.6 \mathrm{~kg} / \mathrm{ha}$. This indicates that application of phosphorus up to $60 \mathrm{~kg} / \mathrm{ha}$ was not economic responsive to increase yield of greengram, if we apply $\mathrm{P}_{2} \mathrm{O}_{5}$ at $49.7 \mathrm{~kg} / \mathrm{ha}$, it gives maximum grain yield which of highly input responsive and further increase in phosphorus dose increases yield with declining rate. For the support of these results, Kumar and Singh, 1993 was found $22.9 \mathrm{~kg}$ $\mathrm{P}_{2} \mathrm{O}_{5} \mathrm{ha}^{-1}$ optimum for grain yield. Khan et al., (1999) also recorded that application of phosphorus from $60-90 \mathrm{~kg} \mathrm{ha}^{-1}$ was optimum for getting better yield of green gram. Sadeghipour et al., (2010) further recorded that application of $120 \mathrm{~kg} \mathrm{P}_{2} \mathrm{O}_{5} \mathrm{ha}^{-1}$ was optimum for fetching the highest yield of green gram.

Correlation coefficients and regression equations were worked out between grain yield of mungbean and dry matter accumulation at harvest, total and effective nodules/plant, fresh and dry weight of nodules/plant, number of pods/plant, number of grains/pod, test weight and total uptake of nitrogen, phosphorus and potassium. The values worked out are presented in table 2 . Results of the correlation coefficients indicated that grain yield was significantly and positively correlated with crop dry matter accumulation at harvest $(r=0.950)$, total and effective nodules/plant ( $\mathrm{r}=0.963$ and 0.944$)$, fresh and dry weight of nodules/plant $(r=$ 0.951 and 0.955$)$, number of pods/plant $(\mathrm{r}=$ $0.972)$, number of grains/pod $(r=0.959)$, test weight $(r=0.945)$, total $\mathrm{N}$ uptake $(\mathrm{r}=0.993)$, total $\mathrm{P}$ uptake $(\mathrm{r}=0.982)$ and total $\mathrm{K}$ uptake $(\mathrm{r}$ $=0.992$ ). The regression equations (Table 2) showed that every unit increase in dry matter accumulation at harvest, total and effective nodules/plant, fresh and dry weight of nodules/plant, number of pods/plant, number of grains/pod, test weight and total uptake of $\mathrm{N}, \mathrm{P}$ and $\mathrm{K}$ increased the grain yield of mungbean by $14.39,46.23,34.82,16.94$, $25.02,22.39,175.32,70.46,8.23,82.98$ and $11.64 \mathrm{~kg} / \mathrm{ha}$, respectively. Sarkar et al., (2002) also recorded as like results.

Interesting result from this experiment was found the significant grain yield and yield attributing variables. The original reason was that optimum levels of phosphorus would be associated with high $\mathrm{N}_{2}$ fixation rates. These results imply that concentrations of $\mathrm{P}$ and bioorganics in the soil alter the crop physiology so that of nitrogen is increased such that the accumulation of dry matter is actually increased. The active loading of dry matter into the phloem for support this energy transfer to whole parts of plants. Phosphorus not only plays important role in root development and proliferation but also improves nodulation and $\mathrm{N}$ fixation by supplying assimilates to the roots. Increased availability of phosphorus owing to its application in soluble form to the soil which was otherwise deficient in $\mathrm{P}$ concentration might have led to significant improvement in the concentration and uptake of this nutrient which in turn helped in early root development and ramification, thereby leading to better growth in terms of plant height, branches/plant and dry matter accumulation. The increased uptake of phosphorus as well as $\mathrm{N}$ and $\mathrm{K}$ due to synergistic effect thereby increasing the sink in terms of flowering and grain setting. These reasons are in close conformity with the findings of Tanwar et al., (2003) and Owla et al., (2007) in mungbean and Singh and Agarwal (2001) in urdbean.

Overall, results from this experimental field to identify any significant correlation, regression interaction in yield and independent variables. 
Table.1 Seed yield (Y) as a function of phosphorus fertilization ( $\mathrm{Y}=\mathrm{b} 0+\mathrm{b} 1 \mathrm{X}$ b2 X2)

\begin{tabular}{|c|c|}
\hline \multirow{2}{*}{\multicolumn{2}{|c|}{$\begin{array}{c}\text { Study parameters } \\
\text { 1.Partial regression coefficients }\end{array}$}} \\
\hline & \\
\hline $\mathrm{b}_{0}$ & 811.8 \\
\hline $\mathrm{b}_{1}$ & $15.165 * *$ \\
\hline $\mathrm{b}_{2}$ & $-0.14125^{*}$ \\
\hline $\begin{array}{l}\text { 2. Coefficients of } \\
\text { (i) Determination }\left(\mathrm{R}^{2}\right) \\
\text { (ii) Multiple correlation }(\mathrm{R})\end{array}$ & $\begin{array}{l}0.999 * * \\
0.999 * *\end{array}$ \\
\hline 3. Optimum level (kg/ha) & 49.679 \\
\hline 4. Yield at optimum level (kg/ha) & 1216.58 \\
\hline 5. Response of optimum level (kg/ha) & 404.78 \\
\hline
\end{tabular}

Note:- The yield, P levels, responses and intercepts are given in $\mathrm{kg} / \mathrm{ha}$

* Significant at $5 \%$ level of significance

** Significant at $1 \%$ level of significance

Fig.1 Seed yield (Y) as a function of phosphorus fertilization $(\mathrm{Y}=\mathrm{b} 0+\mathrm{b} 1 \mathrm{X}$ b2 X2)

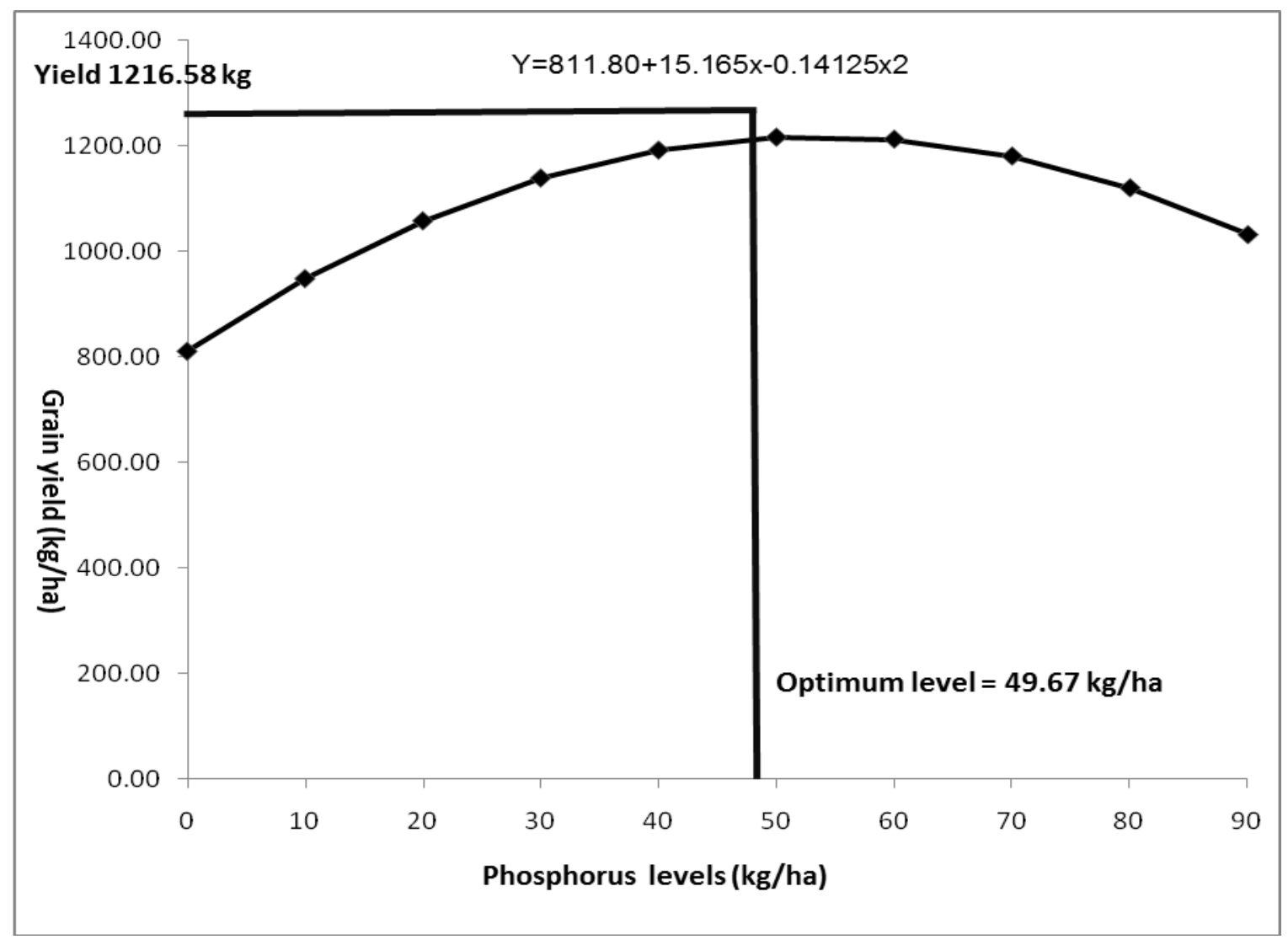


Table.2 Correlation coefficients and linear regression equations showing relationship between grain yield $(\mathrm{kg} / \mathrm{ha})$ and independent variables $(\mathrm{X})$

\begin{tabular}{|c|l|c|l|}
\hline S.No. & Independent variables $(\mathbf{X})$ & $\begin{array}{c}\text { Correlation } \\
\text { coefficients }(\mathbf{r})\end{array}$ & $\begin{array}{c}\text { Regression equations } \\
\left(\mathbf{Y}=\mathbf{a}_{\mathbf{+}} \mathbf{b}_{\mathbf{y x} \cdot \mathbf{X})}\right.\end{array}$ \\
\hline 1. & Dry matter accumulation at harvest $(\mathrm{kg} / \mathrm{ha})$ & $0.950^{* *}$ & $\mathrm{Y}=-550.615+14.398 \mathrm{X}_{1}$ \\
\hline 2. & Fresh weight of nodules/ plant $(\mathrm{mg})$ & $0.951^{* *}$ & $\mathrm{Y}=-851.940+16.943 \mathrm{X}_{2}$ \\
\hline 3. & Dry weight of nodules/plant $(\mathrm{mg})$ & $0.955^{* *}$ & $\mathrm{Y}=-528.368+25.015 \mathrm{X}_{3}$ \\
\hline 4. & Total nodules/plant & $0.963^{* *}$ & $\mathrm{Y}=-423.710+46.228 \mathrm{X}_{4}$ \\
\hline 5. & Effective nodules/plant & $0.944^{* *}$ & $\mathrm{Y}=98.040+34.820 \mathrm{X}_{5}$ \\
\hline 6. & Number of pods/plant & $0.972^{* *}$ & $\mathrm{Y}=359.933+22.391 \mathrm{X}_{6}$ \\
\hline 7. & Number of grains/pod & $0.959^{* *}$ & $\mathrm{Y}=-409.650+175.323 \mathrm{X}_{7}$ \\
\hline 8. & Test weight $(\mathrm{g})$ & $0.945^{* *}$ & $\mathrm{Y}=-1495.604+70.457 \mathrm{X}_{8}$ \\
\hline 9. & Total N uptake $(\mathrm{kg} / \mathrm{ha})$ & $0.993^{* *}$ & $\mathrm{Y}=435.655+8.230 \mathrm{X}_{9}$ \\
\hline 10. & Total P uptake $(\mathrm{kg} / \mathrm{ha})$ & $0.982^{* *}$ & $\mathrm{Y}=505.399+82.982 \mathrm{X}_{10}$ \\
\hline 11. & Total K uptake $(\mathrm{kg} / \mathrm{ha})$ & $0.992^{* *}$ & $\mathrm{Y}=427.316+11.642 \mathrm{X}_{11}$ \\
\hline
\end{tabular}

This may be due to the fact that optimum time is spent by the crop in growing more vegetative parts and yield attributes, hence extending its productivity by improvement for early maturity in green gram. Regression analyses have been carried out between the protein content in grain and $\mathrm{P}$ uptake by the crop. The linear regressions showed every unit dry matter increments increases growth and yield attributes and ultimately yield of crop. All the measured attributes are increased due to optimum phosphorus fertilization and microbial inoculation in to soil, which enhances the availability and amount of essential plant nutrients to the crop, thereby, increases in dry matter accumulation, no. of branches, more no. pods per plant and ultimately increase in yield of crop. Significant and positive correlation existing between grain yields with nutrient uptake also lends support to the higher nutrient concentration. evidenced the above findings, Since, uptake of nutrients is the function of their concentration in plant and grain and straw yields, the higher concentration of these nutrients coupled with significantly higher grain and straw yield improved the total uptake of N, P and K. Protein concentration is essentially the manifestation of $\mathrm{N}$ concentration in grain. Kumawat et al., (2014) in green gram and Sepat and Yadav (2008) in mothbean.

\section{Acknowledgement}

The author is thankful to head Department of Agronomy, SKNAU, Jobner Rajasthan for providing the necessary help for conducting field experiment.

\section{References}

Anonymous. 2014-15a. Directorete of Agriculture Statistics and Economics, Govt. of India, New Delhi.

Anonymous. 2014-15b. Rajasthan Economic review. Commissionerate of Agriculture, Govt. of Rajasthan, Jaipur, 48-56.

Bhatt, P.K., Patel, B.T., Raval, C.H. Vyas, K.G. and Ali, S. 2013. Productivity, quality, nutrient content and soil fertility of summer greengram [Vigna radiata (L) Wilczek] as influenced by different levels of vermicompost and phosphorus with and without PSB. Int. 
J. Agri. Sci., 9(2): 659-662.

Khan, M.A., M.S. Baloch, I. Taj and I. Gandapur. 1999. Effect of phosphorus on the growth and yield of mungbean. Pak. J. Biol. Sci., 2: 667-669.

Kumar, R. and S. Singh. 1993. Effect of plant geometry and phosphatic fertilizer on yield of different varieties of green gram. Crop Res., 6(1): 159-161.

Kumawat, S.R., Khistriya, M.K., Yadav, S.L. and Kumar, M. 2014. Effect of phosphorus fertilization on yield, nutrient content, uptake and quality of summer greengram [Vigna radiata $(\mathrm{L})$ Wilczek]. Environ. Ecol., 32(2A): 785788.

Owla, R.L., Chavan, B.N. and Singh, U. 2007. Effect of plant densities and phosphorus levels on growth and yield of greengram (Vigna radiata). Annals of Agri. Res., 28(1): 95-97.

Sadeghipour, O., R. Monem and A.A. Tajali 2010. Production of Mungbean (Vigna radiata L.) as Affected by Nitrogen and Phosphorus Fertilizer Application. $J$. Appl. Sci., 10(10): 843 - 847.

Sarkar, H.K., Pal, A.K., Baisya, R. 2002. Effect of Bradyrhizobium inoculation on blackgram [Vigna mungo (L.) Hepper] with special reference to root and nodule parameters. $J$. Interacademicia, 6(3): 260-265.

Sathyamoorthi, K. M.Mohamed, A., Vaiyapuri, K. and Somasundaram, E.
2008. Growth and yield of greengram (Vigna radiata (L.)Wilczek) as influenced by increased plant density and nutrient management. Internat. $J$. agric. Sci., 4(2): 499 - 505.

Sepat, S. and Yadav, S.S. 2008. Phosphorus and sulphur management in mothbean (Vigna aconitifolia) under rainfed condition. Annals of Agri. Res., 29: 3842.

Singh, H., P.S. Rathore and A.L. Mali. 1994. Influence of phosphate and inoculation on nutrient uptake recovery and response of applied $\mathrm{P}$ on greengram (Phaseolus radiatus). Indian J. Agron., 39(2): 316-318.

Singh, Y.P. and Aggarwal, R.L. 2001. Effect of sulphur and phosphorus levels on yield and quality of blackgram. Annals of Plant and Soil Res., 3: $\quad$ 298-300.

Tanwar, S.P.S., Sharma, G.L. and Chahar, M.S. 2003. Effect of phosphorus and biofertilizers on yield, nutrient content and uptake by black gram [Vigna mungo (L.) Hepper]. Legume Res., 26(1): 39-41.

Tripura, P., Verma, R.2 and Kumar, S. 2016. effect of potassium humate and bioinoculants on cowpea [vigna unguiculata 1 . walp] influence of soil fertility, enzymatic activity and microbial population in soil. Int. J. Agri. Sci., 8(53): 2638-2641.

\section{How to cite this article:}

Sunil Kumar, S.S. Yadav, Pradip Tripura and H.S. Jatav. 2017. Use of Phosphorus for Maximization of Mungbean [Vigna radiata L. (wilszeck) Productivity under Semi-arid Condition of Rajasthan. Int.J.Curr.Microbiol.App.Sci. 6(2): 612-617. doi: http://dx.doi.org/10.20546/ijcmas.2017.602.069 